\title{
PENURUNAN TINGKAT KECEMASAN PADA LANSIA MELALUI TERAPI MUSIK LANGGAM JAWA
}

\author{
Junaidi $^{1^{*}, Z^{2} \text { Zolkhan Noor }}{ }^{2}$ \\ 1. Program Studi Ilmu Keperawatan Fakultas Kedokteran dan Ilmu Kesehatan Universitas Muhammadiyah Yogyakarta \\ Jl. Lingkar Barat, Tamantirto, Kasihan Bantul, Yogyakarta \\ 2. Fakultas Kedokteran dan Ilmu Kesehatan Universitas Muhammadiyah, Yogyakarta \\ *Email: tarmuloe02@yahoo.co.id
}

\begin{abstract}
Abstrak
Lansia rentan terkena serangan kecemasan. Relaksasi dengan terapi musik dapat mencegah dan menurunkan kecemasan. Terapi musik langgam Jawa diteliti pengaruhnya terhadap penurunan tingkat kecemasan dalam penelitian kuasi eksperimen pre-post with control group ini. Sebanyak 60 sampel penelitian dibagi menjadi dua kelompok, 30 sampel eksperimen dan 30 sampel kontrol diambil secara acak di sebuah panti di Yogyakarta. Instrumen penelitian yang digunakan adalah modifikasi Hamilton Rating Scale for Anxiety $(H R S-A)$ dan terapi dengan kaset campur sari langgam Jawa Waljinah. Ada perbedaan bermakna pada kelompok eksperimen $(\mathrm{p}=0,00, \alpha=0,05)$ dengan penurunan mean 8,58 atau $14,3 \%$ dan penurunan yang bermakna pada kelompok kontrol $(p=0,01, \alpha=0,05)$ dengan penurunan mean 2,04 atau 3,4\%. Terapi musik langgam Jawa secara signifikan dapat menurunkan tingkat kecemasan terutama gejala kecemasan sedang dan berat pada lansia.
\end{abstract}

Kata kunci: kecemasan, lansia, terapi musik

Abstract

Elderly people are susceptible to have anxiety. Relaxation with music therapy may avoid and reduce anxiety. The objective of this quasi experimental pre-post with control group research was to identify the influence of the Langgam Jawa music therapy in reducing anxiety. There were 60 samples taken randomly then divided into two groups, 30 samples was experimental group and 30 samples was control group. The instrument used was modified from the Hamilton Rating Scale for Anxieties (HRS-A) and Campur Sari Langgam Jawa cassette by Waljinah. There are significant differences in the experimental group ( $p$ $=0,00, \alpha=0,05)$ with decrease mean 8,58 or $14,3 \%$ and there was significant degradation in control group $(p=0,01, \alpha=$ 0,05 ) mean degradation 2,04 or 3,4\%. Langgam Jawa music therapy can significantly reduce level of anxiety especially moderate and severe anxiety in elderly.

Keywords: anxiety, elderly, music therapy

\section{Pendahuluan}

Kecemasan adalah respons emosional terhadap penilaian yang menggambarkan keadaan khawatir, gelisah, takut, dan tidak tenteram disertai berbagai keluhan fisik. Keadaan tersebut dapat terjadi dalam berbagai situasi kehidupan manapun sebagai gangguan penyakit (Vida, 2004). Sedangkan menurut Pietra (2001) dan Haryanto, et al. (2004) kecemasan adalah adanya reaksi yang menjadi nyata atau bayangan ancaman dan perasaan umum dari tidak aman atau rasa takut. Masalah kecemasan adalah masalah yang kompleks sehingga perlu penanganan serius.

Prevalensi kecemasan di Indonesia berkisar antara 2$5 \%$ dari populasi umum yang disebabkan oleh berbagai faktor (Rehatta, 1999). Konsep psikoneuroimunologi menjelaskan kecemasan sebagai stresor yang bisa menurunkan imun tubuh. Hal ini terjadi melalui serangkaian aksi yang diperantarai oleh aksis Hipotalamus-Hipofisis-Adrenal sehingga merangsang hormon hipofisis anterior untuk meningkatkan produksi ACTH (Adrenocorticotropic hormone). Hormon ini akan merangsang korteks adrenal untuk meningkatkan sekresi kortisol yang selanjutnya akan menekan sistem imun tubuh (Rehatta, 1999; Guyton \& Hall, 1997).

Sekitar 6\% penduduk Indonesia berusia 60 tahun ke atas dan 3\% berusia 65 tahun ke atas atau lebih. Yogyakarta adalah barometer lansia secara nasional seiring dengan meningkatnya angka harapan hidup penduduk di Yogyakarta (Nugroho, 2008). 
Data kantor statistik Daerah Istimewa Yogyakarta (DIY) pada tahun 1990 menunjukan jumlah lansia pada sensus penduduk tahun 1990 yaitu 317.043 orang (Witiarto, 2001).

Kecemasan khususnya pada lansia semakin hari dapat cenderung semakin meningkat karena banyaknya faktor dari dalam tubuh lansia yang dapat mempengaruhi kecemasan misalnya penurunan fungsi organ. Lansia yang berada di panti dapat mengalami peningkatan kecemasan karena faktor lingkungan dan sosial dalam kehidupan sehari-hari di panti.

Survei pendahuluan di sebuah panti di Yogyakarta sebagai lokasi penelitian menunjukkan bahwa lebih dari $80 \%$ dari total 100 penghuni panti mengalami kecemasan yang beragam mulai dari ringan sampai berat. Angka kecemasan ini termasuk tinggi bahkan untuk ukuran Yogyakarta yang dijadikan barometer lansia di Indonesia. Hal ini membuktikan bahwa kecemasan menjadi salah satu masalah yang perlu ditangani di panti ini.

Angka kecemasan yang tinggi dan faktor penyebabnya yang cukup kompleks memerlukan penanganan yang serius, salah satu pilihannya adalah dengan teknik relaksasi (Budiarti et al., 2006). Salah satu teknik relaksasi yang dapat digunakan adalah terapi musik (National Safety Council, 2004). Pilihan musik merupakan hal yang penting karena musik yang dikenal sebelumnya dipercaya lebih efektif untuk mengatasi kecemasan (Salve \& Prabowo, 2007; Setiadarma, 2002). Oleh karena itu, pemilihan jenis musik disesuaikan dengan kultur populasi yakni pada penelitian yang melibatkan populasi Jawa dan berlokasi di Yogyakarta ini digunakan terapi musik langgam Jawa. Penelitian ini bertujuan mengetahui pengaruh terapi musik langgam jawa terhadap tingkat kecemasan pada lansia.

\section{Metode}

Metode penelitian ini adalah kuasi eksperimen dengan rancangan pre-post test with control group. Rancangan ini berupaya untuk mengungkapkan hubungan sebab akibat dengan melibatkan kelompok kontrol dan eksperimen. Pemilihan kedua kelompok ini menggunakan teknik random sampling dengan membagi menjadi dua kelompok (Arikunto, 1997). Penelitian melibatkan 60 orang lansia yang mengalami kecemasan dari total 100 orang lansia yang tinggal di Panti. Sejumlah masing-masing 30 sampel dipilih secara acak untuk diberi perlakuan dan atau sebagai kelompok kontrol. Data diambil melalui teknik wawancara dengan bantuan modifikasi kuesioner Hamilton Rating Scale (HRS-A). Sedangkan, posttest dilakukan kepada semua partisipan penelitian baik kelompok eksperimen maupun kontrol. Semua subjek penelitian bersuku Jawa sehingga dapat diambil sebagai prasyarat inklusi yakni di wisma A, C, dan E.

Total enam ruangan/wisma yang ada di tempat penelitian yaitu sebuah Panti Werdha di Yogyakarta. Wisma A, C, E dijadikan kelompok perlakuan dan wisma B, D, F sebagai kelompok kontrol. Pembagian kelompok berdasarkan wisma ini bertujuan agar kelompok kontrol dan perlakuan tidak tercampur. Lansia yang berada di Wisma B, D, dan F tidak diberi ijin oleh pihak Panti untuk berkunjung ke ruangan sampel selama proses penelitian dan saat istirahat siang diatur sehingga warga Panti dapat berdiam di kamar untuk istirahat.

Penelitian ini berpedoman pada prinsip-prinsip etika antara lain: tidak membahayakan sampel, menghargai kehormatan sampel, dan memperlakukan sampel secara adil. Setiap sampel telah mendapat penjelasan mengenai tujuan, manfaat penelitian, serta jaminan kerahasiaan informasi yang diberikan sampel kepada peneliti. Penelitian dilakukan setelah masing-masing sampel menyetujui melalui informed consent.

\section{Hasil}

Rentang usia pada masing-masing kelompok sampel adalah sama yakni usia 60 tahun ke atas. Jumlah responden terbanyak adalah wanita yakni 23 sampel pada kelompok kontrol dan 20 sampel pada kelompok eksperimen. Jumlah responden pria pada kelompok kontrol dan eksperimen masing-masing 7 dan 10 . Status perkawinan sebagian besar adalah janda dan duda. Pada kelompok eksperimen terdapat 19 orang janda dan 9 duda, sedangkan kelompok kontrol terdapat 23 orang janda dan 7 duda (lihat tabel 1). 
Tabel 1. Karakteristik Responden Berdasarkan Usia dan Jenis Kelamin

\begin{tabular}{lcccccc}
\hline $\begin{array}{c}\text { Kelompok } \\
\text { Sampel }\end{array}$ & $\begin{array}{c}\text { Rerata } \\
\text { Usia }\end{array}$ & $\begin{array}{c}\text { Jenis Kelamin } \\
\text { Laki-laki }\end{array}$ & $\begin{array}{c}\text { Rerata lama } \\
\text { Perempuan }\end{array}$ & $\begin{array}{c}\text { Status } \\
\text { pernikahan }\end{array}$ & $\begin{array}{c}\text { Pen yakit yang } \\
\text { diderita }\end{array}$ \\
\hline Eksperimen & $\geq 60$ & 10 & 20 & 3 bulan-20 tahun & $\begin{array}{c}9 \text { duda } \\
19 \text { janda }\end{array}$ & $\begin{array}{c}2 \text { hipertensi } \\
4 \text { rematik }\end{array}$ \\
& & & & & suami-istri & $\begin{array}{c}23 \text { keluhan somatik } \\
7 \text { hipertensi } \\
7 \text { rematik }\end{array}$ \\
Kontrol & $\geq 60$ & 7 & 23 & 3 bulan-20 tahun & $\begin{array}{c}7 \text { janda } \\
4 \text { keluhan somatik }\end{array}$ \\
\hline
\end{tabular}

Hanya sedikit responden yang hidup secara bersamasama, yakni sepasang suami istri. Penyakit yang diderita responden sangat beragam seperti hipertensi, rheumatik, dan yang terbanyak adalah keluhan somatik.

Teknik pemberian terapi musik adalah dengan mendengarkan musik langgam Jawa pada jam-jam tertentu sebagai pengantar istirahat. Jenis musik yang digunakan antara kaset yang satu dengan yang lainnya sama, sehingga memiliki homogenitas alat uji.

Hasil analisis tingkat kecemasan responden kelompok eksperimen sebelum diberi terapi musik langgam Jawa memperlihatkan bahwa responden mengalami tingkat kecemasan sedang $(33,33 \%)$ dan berat $(40 \%)$. Kemudian setelah diberikan terapi musik Langgam Jawa, tingkat kecemasan berkurang yaitu menjadi $3,33 \%$ sedang dan $0 \%$ berat.

Tingkat kecemasan responden kelompok kontrol sebelum diberi terapi musik langgam Jawa menunjukkan gejala kecemasan sedang $(23,33 \%)$ dan berat $(23,33 \%)$. Setelah enam minggu, dilakukan pengukuran kembali dan didapatkan peningkatan gejala kecemasan yaitu cemas sedang $(30 \%)$ dan berat (70\%). Analisis ini hanya dilakukan pada hasil mayoritas atau yang diakibatkan naik atau turunnya angka pre test dan post test (lihat tabel 2).

Hasil uji stastistik pada kelompok kontrol pre test didapatkan mean sebesar 19,57, t-hitung -54,79, SD $7,04(\mathrm{p}=0,00, \alpha=0,05, \mathrm{CI} 95 \%)$. Pengukuran pre test kelompok eksperimen didapatkan hasil mean sebesar 25,33, t hitung -50,21, SD 7,05 ( $\mathrm{p}=0,00$, $\alpha=0,05)$. Sedangkan, hasil akhir post test pada kelompok kontrol didapatkan mean 17,53, t hitung 47,42, SD 8,37 ( $p=0,00, \alpha=0,05)$. Hasil akhir pengukuran post test kelompok eksperimen menunjukkan mean 16,80, thitung -60,47, SD 16,80 $(p=0,00, \alpha=0,05)$ (lihat tabel 3).

\section{Pembahasan}

Rerata usia antar kelompok sampel saling mendekati dan hampir sama. Responden berjenis kelamin wanita lebih banyak yakni sebesar $71,66 \%$, sedang responden berjenis kelamin pria sebesar $28,33 \%$. Rerata lama tinggal di panti adalah tiga hingga 20 tahun, baik pada kelompok eksperimen maupun kelompok kontrol. Status pernikahan yaitu $90 \%$ janda dan duda, hanya satu pasangan. Jenis penyakit yang diderita antara kelompok kontrol dan eksperimen bersifat homogen. Akan tetapi terdapat perbedaan jumlah yang signifikan, yakni pada kelompok eksperimen reponden yang mengalami hipertensi berjumlah dua orang, mengalami keluhan reumatik sebanyak 4 orang, dan 23 responden mengalami keluhan somatik. Sedangkan pada kelompok kontrol sebanyak sembilan orang mengalami hipertensi, jumlah penderita rheumatik sebanyak 13 orang serta 14 yang mengalami keluhan somatik.

Faktor perancu dikaji dengan pengukuran sama subjek dan beda subjek untuk mengetahui ada atau tidak perbedaan hasil pre test pada masing-masing kelompok. Pengukuran sama subjek dan beda subjek dilakukan dengan cara berikut: hasil pre test kelompok kontrol dibanding pre test kelompok eksperimen, hasil pre test perlakuan dengan hasil pre test eksperimen dan pre test kontrol dengan hasil pre test kontrol. Hal ini dilakukan untuk melihat penurunan awal. 
Tabel 2. Distribusi Frekuensi Kategori Tingkat Kecemasan Kelompok Eksperimen dan Kontrol Sebelum dan Sesudah Intervensi

\begin{tabular}{lcccc}
\hline Kategori Tingk at Kecemasan & & Sebelum & Freku ensi & Sesu dah \\
& $\mathbf{n}$ & $\mathbf{\%}$ & $\mathbf{n}$ & $\mathbf{\%}$ \\
\hline Eksperimen & 1 & 3.33 & 11 & 36.66 \\
$\quad$ Tidak ada gejala & 7 & 23.33 & 10 & 33.33 \\
Gejala ringan & 10 & 33.33 & 8 & 26.66 \\
Gejala sedang & 2 & 40 & 1 & 3.33 \\
Gejala berat & 0 & 0 & 0 & 0 \\
Gejala berat sekali & & & & \\
Kon trol & 9 & 30 & 11 & 36.66 \\
Tidak ada gejala & 7 & 23.33 & 6 & 20 \\
Gejala ringan & 7 & 23.33 & 9 & 30 \\
Gejala sedang & 7 & 23.33 & 21 & 70 \\
Gejala berat & 0 & 0 & 0 & 0 \\
Gejala berat sekali & & & & \\
\hline
\end{tabular}

Tingkat kecemasan yang dialami setelah pengukuran kuesioner dengan teknik wawancara didapatkan bahwa gejala kecemasan yang paling sedikit berada pada rentang antara angka satu hingga 14. Angka satu berarti tidak ada gejala kecemasan dan angka yang paling besar menunjukkan kecemasan berat pada kelompok eksperimen. Sedangkan pada kelompok kontrol angka yang paling besar berada pada rentang nilai satu sampai dengan 14 berarti tidak ada kecemasan. Sedangkan pada kecemasan ringan, sedang, dan berat sama-sama memiliki jumlah angka tujuh, sedangkan pada kedua sampel penelitian tidak didapatkan memiliki kecemasan berat sekali.

Tingkat kecemasan pada masing-masing responden baik pada kelompok eksperimen maupun pada kelompok kontrol didapatkan hasil yang beragam setelah penghitungan nilai akhir kuesioner pada tiaptiap pertanyaan dengan nilai yang paling sedikit berada pada tidak adanya gejala kecemasan dan paling banyak terdapat pada kecemasan berat.

Pada responden kecemasan kelompok eksperimen sesudah dilakukan tindakan dengan pemberian terapi musik langgam jawa terdapat penurunan tingkat kecemasan dari kecemasan berat 12 responden (40\%) menjadi satu responden $(3,33 \%)$, gejala sedang 10 responden $(33,33 \%)$ turun menjadi delapan responden $(26,66 \%)$, dari beberapa responden antara tingkat kecemasan tanpa gejala ( 0 sampai nilai 14 pada hasil uji kuesioner) dan gejala ringan (15 sampai dengan nilai 20 pada hasil uji kuesioner) mengalami sedikit peningkatan diakibatkan oleh penurunan yang sangat berarti dari gejala berat dan sedang menjadi ringan dan tanpa gejala yakni $23.33 \%$, pada gejala ringan menjadi $33.33 \%$, dan pada tanpa gejala kecemasan dari $33.33 \%$ menjadi $36.66 \%$. Artinya, penurunan sangat berarti pada gejala berat dan sedang.

Sesuai dengan penelitian dari Budiarti, et al. (2006) bahwa pemberian terapi musik langgam jawa dapat memberikan efek ketenangan dan berakibat pada penurunan kecemasan dengan cara menurunkan ekskresi hormon kortisol dan pengaturan denyut jantung sehingga pembentukan imunitas akan tinggi.

Hasil uji stastistik dengan uji normalitas didapatkan angka 0,20 dan 0,12 (lebih besar dari 0,05) baik pada pria maupun wanita sehingga dapat diartikan bahwa data terdistribusi normal. Selanjutnya data yang didapat diuji dengan statistik parametrik Uji Paired Simple t Test dan untuk mengetahui sebaran hasil sebelum dan sesudah perlakuan sesama sampel dan lain sampel pada kelompok eksperimen dan pengukuran pre test dan post tes tanpa perlakuan pada kelompok kontrol dengan One Samples t Test.

Hasil penelitian uji statistik menunjukkan bahwa ada pengaruh terapi musik langgam Jawa terhadap penurunan respon psikologis kecemasan pada lansia. 
Hal ini disebabkan dengan mendengarkan musik tempo lamban atau sekitar 60 beat per menit yang dimiliki oleh musik langgam Jawa dapat memperlambat dan menyeimbangkan gelombang otak yang menandakan ketenangan. Hal ini terjadi karena dengan stimulasi binaural-beat dapat mendorong seseorang untuk kembali kedalam kesadaran (Campbell, 2002; Salve \& Prabowo, 2007).

Musik antara 56 sampai 60 beat per detik dapat digunakan untuk melatih relaksasi dan gelombang otak menuju kekeadaan alfa (Salve \& Prabowo, 2007; Chan, 1998). Dalam keadaan tenang seseorang akan memiliki substansi yang memiliki beta karbolin, yaitu antagonis GABA yang menyebabkan penurunan jumlah down regulator receptor GABA. Penurunan ini yang akan mengurangi hambatan terhadap timbulnya kecemasan (Sholeh, 2005).

Penurunan respons psikologis kecemasan bisa disebabkan karena mendengarkan musik merupakan salah satu bentuk relaksasi yang bisa mensinkronisasi ritme tubuh dengan cara adanya fibrasi serta bisa menstimulasi seseorang untuk merasakan ketenangan (Pratiwi, 2008). Rasa nyaman yang timbul pada saat mendengarkan musik dapat diakibatkan karena kelenjar hiposifis melepaskan endorfin, yang terjadi akibat aktivitas elektrik yang tersebar di regio-regio otak yang berhubungan dengan sistem limbik dan pusat kontrol otonomi (Campbell, 2002; Ester, 2002; McGregor, 2001). Dengan mendengarkan musik yang disukai, maka seseorang akan merasa lebih santai yang akhirnya bisa menurunkan ketegangan dan kecemasan terhadap stresor yang dihadapi.
Penurunan dari gejala ringan juga dialami pada kelompok kontrol yaitu sebanyak tujuh responden $(23.33 \%)$ menjadi enam responden (20\%), sedangkan pada gejala yang lainya mengalami peningkatan yang sangat signifikan yakni gejala sedang dari tujuh responden $(23.33 \%)$ menjadi sembilan $(30 \%)$, gejala berat dari tujuh responden $(23.33 \%)$ meningkat menjadi 21 responden $(70 \%)$, dan tidak ada yang mengalami gejala yang berat sekali $(0 \%)$.

Hasil uji statistik menunjukkan terdapat perbedaan pada kelompok kontrol tanpa pemberian perlakuan, mengalami penurunan pada gejala ringan dari $23.33 \%$ menjadi 20\%, hal ini mungkin disebabkan karena para responden kelompok kontrol juga mengikuti kegiatan senam yang diadakan setiap pagi di PSTW. Penurunan ini tidak begitu signifikan.

Terjadinya peningkatan kecemasan pada kelompok kontrol dilihat dari hasil statistik memiliki angka yang sangat berarti yakni pada gejala sedang dari tujun responden $(23.33 \%)$ menjadi sembilan responden atau sebanyak (30\%), serta gejala berat dari tujuh orang responden $(23.33 \%)$ meningkat menjadi 21 orang responden atau naik menjadi $(70 \%)$.

Peningkatan pada kelompok kontrol mungkin dipengaruhi oleh frustasi yang diakibatkan oleh tidak tercapainya tujuan yang diingini, adanya konflik diakibatkan oleh individu tidak dapat memilih diantara dua atau lebih dari macam kebutuhan, adanya tekanan yang akan menyebabkan stressor lebih serta krisis yang dialami dimana perubahan keadaan yang mendadak sehingga menimbulkan kecemasan, seperti kematian atau kehilangan yang mendadak.

Tabel 3. Rerata Skor Tingkat Kecemasan Sebelum dan Sesudah Perlakuan pada Kelompok Eksperimen dan Kelompok Kontrol dengan Perbandingan Pengukuran Sama Subjek

\begin{tabular}{lcccc}
\hline \multicolumn{1}{c}{ Kelompok Sampel } & Mean & Hasil t-Test & SD & Sig. \\
\hline $\begin{array}{l}\text { Pre test } \text { Kontrol vs } \\
\text { Post test } \text { Kontrol }\end{array}$ & 19.57 & -54.79 & 7.04 & 0.00 \\
& 17.53 & 11.47 & 8.37 & 0.00 \\
Pre test Eksperimen vs & & 19.67 & 7.05 & 0.00 \\
Post test Eksperimen & 25.33 & 13.87 & 6.63 & 0.00 \\
\hline
\end{tabular}


Hasil uji statistik sebelum dan sesudah perlakuan pada kelompok eksperimen didapatkan hasil t hitung sebesar 2.654 serta nilai signifikansi diperoleh $p=0,000$ masih jauh dari $p=0,05$. Pengaruh pemberian terapi musik langgam Jawa terhadap tingkat kecemasan pada lansia yakni sebesar 0,477 sehingga $R$ square dapat disebut koefisien determinasi, dalam hal ini berarti 43.27\% penurunan tingkat kecemasan dipengaruhi oleh musik langgam jawa. Penurunan ini disebabkan karena pengunaan musik sebagai relaksasi, diketahui bahwa relaksasi dapat membantu meningkatkan pemahaman mengenai penurunan ketegangan otot dan kecemasan dapat dibenarkan.

Pada bagian otot, dengan penggunaan musik yang dikenal dan disukai sebelumnya dapat menurunkan sekresi asam laktat dan zat-zat kinin sehingga rasa sakit atau nyeri yang disebabkan oleh kecemasan dapat berkurang. Sedangkan pada derajat kecemasan, seseorang yang memilih musik yang disukainya akan terbawa ke keadaan tenang dengan perubahan mood ke lebih baik, sehingga hormon endorfin dalam tubuh akan keluar dan ketenangan akan meningkat (Jabrohim, 2008). Selebihnya penikmat musik ini akan menekan pengeluaran hormon kortisol atau hormon stres sehingga lambat laun pembentukan imunitas tidak terganggu. Mendukung hasil penelitian Eder (2001) dalam Haryanto, et al., (2004) menyatakan bahwa peningkatan imunitas ini adalah dengan cara meningkatkan opiat endogen (endorfin dan enkefalin) serta menurunkan katekolamin sehingga daya tahan tubuh penderita meningkat. Hal ini dimungkinkan karena mekanisme terciptanya kenyamanan jiwa, ketika telinga kita menangkap suara musik yang lembut dapat memperlambat detak jantung, memperhalus kerja nafas dan akhirnya menyamankan jiwa (Bullock et al., 2001).

Kelompok kontrol juga mengalami penurunan, hal ini diduga efek dari pengunaan terapi lainnya seperti obatobatan dan latihan fisik (olah raga) yang selalu rutin dilakukan oleh kelompok kontrol di tempat penelitian seperti senam lansia, diketahui bahwa senam juga akan menurunkan kecemasan (Manz, 2007). Latihan yang berulang-ulang akan merangsang otak untuk menghasilkan sejumlah sinyal sehingga kimia darah dapat selalu berada dalam rentang normal (Guyton \& Hall, 1997; Manz, 2007).

Pengukuran dengan regresi didapatkan hasil angka berada pada rentang-rentang angka yang menunjukkan pengaruh yang signifikan atau ada hubungan antara sebab akibat, karena t hitung terletak pada $\mathrm{H}_{\mathrm{o}}$ ditolak, maka dapat disimpulkan bahwa pada kelompok eksperimen lebih signifikan penurunan tingkat kecemasannya setelah perlakuan dengan terapi musik langgam jawa. Berdasarkan nilai signifikansi yang dimiliki masing-masing kelompok variabel, dimana tingkat signifikansi kelompok eksperimen $p=0.000<$ 0,05 , tingkat signifikansi kelompok kontrol $p=0.001<$ 0,05 .

\section{Kesimpulan}

Kelompok perlakuan dengan pemberian terapi musik langgam Jawa selama enam minggu mengalami penurunan kecemasan dari awal 25,33 turun menjadi 16,80 , penurunan angka sebasar 8.58 poin dengan $\mathrm{p}=0.000(<0.05)$. Hal ini dapat diartikan bahwa setelah dilakukan post-test didapatkan hasil yang menyatakan perbedaan yang sangat bermakna pada kelompok eksperimen. Sehingga dapat diartikan bahwa terapi musik langgam jawa terbukti lebih efektif dalam menurunkan tingkat kecemasan dibandingkan kelompok kontrol tanpa perlakuan terapi musik langgam jawa yakni dari pre tes 19.57 menjadi 17.53 pada pos test, turun sebesar 2.02 poin atau $\mathrm{p}=0.001$ $(<0.05)$ penurunan poin jauh di bawah kelompok perlakuan. Diseminasi manfaat terapi musik langgam Jawa perlu dilakukan untuk memperluas pemanfaatannya sebagai salah satu alternatif menurunkan kecemasan terutama pada kelompok lansia (TH, INR).

\section{Referensi}

Arikunto, S. (1997). Prosedur penelitian: Suatu pendekatan praktik (edisi revisi V). Jakarta: Rineka Cipta.

Budiarti, A., Sutjahjo, R.A., Kusnanto, \& Dian, N.K. (2006). Pengaruh terapi musik langgam Jawa terhadap penurunan kecemasan pasien preoperasi 
katarak. Pioners Majalah Keperawatan UNAIR, 9-13.

Bullock. (2001). Human and pathophysiology. Philadelphia: Lippincott.

Campbell, D. (2002). Efek Mozart: Memanfaatkan kekuatan musik untuk mempertajam pikiran, meningkatkan kreativitas \& menyehatkan tubuh. Jakarta: Gramedia Pustaka Utama.

Chan, L. (1998). Music therapy for anxiety of respiration patient. Heart-Lung Ester. 2002. Efects of music on patient anxiety. Diperoleh dari www.findartikel.com.

Ester. (2002). Efects of Music on Patient anxiety. Diperoleh dari www.findartikel.com.

Guyton, \& Hall. (1997). Fisiologi kedokteran. Jakarta: EGC. (Terjemahan bahasa indonesia).

Haryanto, J., Kusnoto, \& Sumarno, A. (2004). Efek teknik relaksasi progresif pada klien dengan nyeri akibat penyakit glaukoma. Jurnal Penelitian Medika Eksakta, 5, 24.

Jabrohim. (2008). Mengurangi depresi lewat seni musik. Diperoleh dari http://suara-muham madiyah.com/?p=455.

Manz, C.C. (2007). Manajemen emosi.Think. Jogjakarta. Hal 175, 181-182.

McGregor, S. (2001). Piece of mind: Menggunakan kekuatan pikiran bawah sadar untuk mencapai tujuan. Jakarta: Gramedia.

National Safety Council. (2004). Managemen Stress. Jakarta Penerbit: Buku Kedokteran EGC.

Nugroho. (2008). Keperawatan "Gerontik \& geriatrik”. Jakarta: Penerbit Buku Kedokteran EGC.
Pietra, A. (2001). Pengaruh kecemasan dalam proses persalinan dan cara mengatasinya. Skripsi Strata Satu, Universitas Muhammadiyah Yogyakarta. Yogyakarta: Universitas Muhammadiyah Yogyakarta.

Pratiwi, R.P. (2008). Terapi musik. Diperoleh dari http://siarindonesa.net/utty/2008/10/15/terapimusik/.

Rehatta, N.M. (1999). Pengaruh pendekatan psikologis prabedah terhadap toleransi nyeri dan respon ketahanan imunologik pasca bedah (Disertasi, Pasca Sarjana Universitas Airlangga). Universitas Airlangga, Surabaya.

Salve, H.R., \& Prabowo, H. (2007). Treatment metamusic untuk menurunkan stress (Tesis Pasca Sarjana). Universitas Gunadarma, Jakarta.

Setiadarma, P.M. (2002). Painting with heart: Apa dan bagaimana manfaatnya melalui perspektif psikologi. Seminar dan Workshoop Art Therapy. Jakarta: Fakultas Psikologi Universitas Indonesia.

Sholeh, M. (2005). Tahajud, terapi religius: Manfaat praktis ditinjau dari ilmu kedokteran. Yogyakarta: Pustaka Pelajar.

Vida, N. (2004). Hubungan antara pengetahuan menopouse dengan kecemasan pada wanita dalam menghadapi masa menapouse di Desa Kotesan Kecamatan Prambanan Kabupaten Klaten (Skripsi, Universitas Muhammadiyah Yogyakarta). Yogyakarta: Universitas Muhammadiyah Yogyakarta.

Witiarto. (2001). Problem-problem psikologis pada USILA (Skripsi, Universitas Muhammadiyah Yogyakarta). Yogyakarta: Universitas Muhammadiyah Yogyakarta.

Manusia dapat mengubah kehidupannya dengan mengubah sikap pikiran mereka.

- William James - 